\title{
W I A
}

\section{KRONIKA RUCHULITURGICZNEGO \\ STOLICA ŚWIĘTA}

Dnia 13 grudnia 1957 r. Św. Kongregacja Obrzędów wydala dekret upoważniający Konferencje Biskupów poszczególnych krajow do określania procentu zawartości wosku w świecach przeznaczonych do użytku liturgicznego.

Dnia 15 grudnia 1957 r. Św. Kongregacja Obrzędów opublikowała nową Instrukcję w sprawie odprawiania Mszy św. przez kapianów niedowidzacych, uwzględniająca zasady dekretu o uproszczeniu rubryk.

Przy Papieskim Ateneum Lateraneńskim utworzono Papieski Instytut Duszpasterstwa. Instytut obejmuje dwa kursy: niżsy, jednoroczny, dla przygotowania kapłanów świeckich i zakonnych do zadań duszpasterskich oraz wyższy, dwuletni, przygotowujacy profesorów teologii duszpasterskiej. Wśród przedmiotów wykłada się również liturgię pastoralną.

Pierwszy numer miesiecznika Fede et arte z r. 1957 podaje. akta VIII Tygodnia sztuki kościelnej. Numery 10--11 tegoż pisma zawierają dokumenty Stolicy Św. odnoszące się do sztuki kościelnej zestawione w porzacku chronologicznym od św. Grzegorza Wielkiego do Piusa XII.

\section{ARGENTYNA}

Episkopat Argentyński powołał Komisje Liturgiczna, która mis opracować nowy rvtuał oraz jednolity przekład Ordinatorium. Missae.

\section{AUSTRALIA}

W dniach 20-24 stycznia 1958 odbył siẹ w mieście Mauly $\mathrm{Na}$ rodowy Tydzień Duszpasterski poświęcony problemom życia duchowego parafii a zwłaszcza duszpasterstwu liturgicznemu. Omówiono następujace tematy: Parafia w życiu Kościoła, Uświęcenie. kapłana w działalności przez kult, Uświęcenie kapłana w dzia-- 
łalności (kapłan i apostolstwo stowarzyszeń), Uświęcenie wiernych przez kult liturgiczny i pozaliturgiczny, Uświęcenie wiemych w działalności.

\section{AUSTRIA}

Dnia 14 marca 1957 odbyła się w Instytucie liturgicznym Opactwa św. Piotra w Salzburgu XVII krajowa konferencja liturgiczna pod przewodnictwem J. E. 'Zaunera, biskupa Linzu, poświęcona odrodzeniu liturgii $W$. Tygodnia. Postanowiono zachować Boży Grób, a procesję rezurekcyjną odprawiać bezpośrednio po Mszy Wigilii Wielkanocnej. Z radością przyjęto możliwość odprawiania funkcji W. Tygodnia z samym diakonem. Omawiano sprawę wprowadzenia dzieci w czynny udział we Mszy św.

Dnia 30 października 1957 w tejże siedzibie odbyła się XVIII Krajowa Konferencja liturgiczna poświęcona fcrmom udziału wiernych we Mszy św.

$\mathrm{Na}$ rok 1959 zapowiedziano międzynarodowy Kongres zakrystianów we Wiedniu pod hasłem: Miłuję, Panie, piękno domu twego.

\section{FRANCJA}

Problem języków żywych w liturgi pod względem prawnym omawia M. Michaud. Langue d'Elise et droit liturgique w L'année canonique, 2 (1954-1955) 99-128). Autor udowadnia możliwość i właściwość wprowadzania języków żywych do liturgii.

We Francji powstało "Towarzystwo św. Ambrożego" dla popierania śpiewu ludu. Towarzystwo to rozpoczęło wydawanie miesięcznika Eglise qui chante. Pierwszy numer ukazal się w Adwencie 1957. Pismo propaguje tak śpiew ściśle liturgiczny, jak śpiew w języku żywym.

Rozpoczęto wydawanie dwutygodnika ,Feu nouveau" przy współpracy francusko-belgijskiej. Nowe pismo przeznaczone dla świeckich chce ich wprowadzić w zrozumienie Pisma św i liturgii.

„La vie spirituelle" poświęciło swój numer 456 z lutego 1958, stuleciu objawień w Lourdes. Zawiera on komentârz O. Moos O, P., do psalmów gradualnych używanych w Officium Parvum B. $M . V$., artykuł O. Humberta O. P. Różaniec a liturgia, oraz rozważania o tajemnicach różańcowych ścile oparte na Piśmie św.

\section{HISZPANIA}

W Cuenca odbył siẹ 4 Kongres duszpasterstwa liturgicznego. Zająl sie on specjalnie liturgia chorych i pogrzebowa oraz jej stroną duszpasterską. Referaty były oparte przeważnie o nową literaturę francuska tego przedmiotu. Odprawiono uroczyście całkowicie w języku hiszpańskim wigilie biblijną. 
Opactwo w Montserrat zorganizowało pierwszy tydzień studiów liturgicznych. Tydzień ten poświęcono studiom nad starym rytuałem mozarabskim i jego stosunkiem do rytuału rzymskiego. Okazalo się, że język żywy miał bardzo szerokie zastosowanie w starym rytuale, zwłaszcza na terenie diecezji Tarragona. Oczekuje się, że owocem tego tygodnia studiów będzie opracowanie rytuału dwujęzycznego dla Hiszpanii.

\section{NIEMCY}

21 maja $195 ' 7$ zmarł w Berlinie, w czasie wygłaszania przemówienia do nowożeńców, Dr Johannes Pinsk. Był on czołowa postacia ruchu liturgicznego w Niemczech. W r. 1929 założył pismo Liturgische Zeitschrift, które w r. 1943 zmienilo tytuł na Liturgisches Leben. Pozostawał $\mathrm{w}$ ścisłej współpracy $\mathrm{z}$ opactwem Maria-Laach, którego zdobycze naukowe umiejętnie wykorzystywał w duszpasterstwie; opublikował cały szereg artykułów i książek wprowadzających $\mathrm{w}$ duchowość liturgiczną, w sakramentalny świat. Wiele $z$ nich tłumaczono na języki obce.

F. Pustet rozpoczą wydawanie nowej Encyklopedii p. t. Lexikon der Marienkunde. Dzieło to ma objąc zagadnienie dogmatyczne, biblijne, hagiograficzne, liturgiczne oraz omówić wszelkie formy czci M. Bożej.

\section{WE E R Y}

W dniach 21-23 sierpnia 1957 w Budapeszcie, obradowali deleģaci Biskupów Wegier dla spraw liturgii. Przedmiotem narad był świeżo przygotowany rytuał dwujezyczny dla Wegier oraz Wielki Tydzień. Postanowiono przedłożyć Św. Kongregacji Obrzẹdow do aprobaty nowy jednolity rytuał łacińsko-węgierski, w którym zachowano kilka właściwości krajowych, pochodzacych ź rytuału Ostrzyhomskiego. Przy tłumaczeniu tekstów liturgicznych uiyto współczesnego języka literackiego. Podkreślono konieczność duszpasterskiego przygotowania W. Tygodnia. Wyłoniono Komisję, kióra przygotuje prośbe do Stolicy Św. o skrócenie Wigilii Wielkanocnej, a zwłaszcza ,Exultet" i Prefacji przy poświęceniu wody chrzcielnej.

Dnia 28. IX. 1957 w Ostrzyhomiu, otwarto wystawe ksiag iluminowanych. Wśód nich przeważają księgi liturgiczne.

\section{Opracował O. FRANCISZEK MAEACZYŃSKI OSB.}

